The

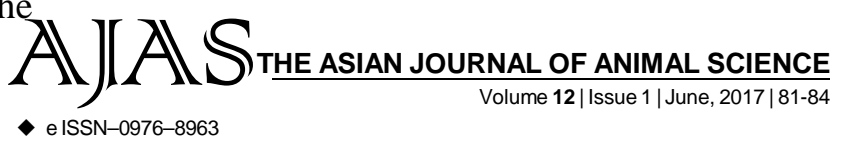

DOI : 10.15740/HAS/TAJAS/12.1/81-84 Visit us | www.researchjournal.co.in S

\title{
Effect of turmeric (Curcuma longa) powder in diet on growth performance of broiler chicks
}

DILEEP KUMAR AND U.K. SHUKLA

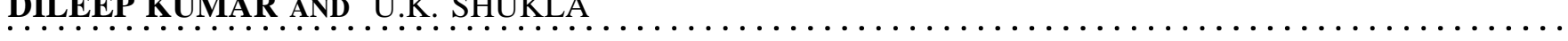

Author for Corresponding -

\section{DILEEP KUMAR}

Department of Animal Science, Livestock Production and Management, Faculty of Agriculture, Mahatma Ganghi Chitrakoot Gramodaya Vishwavidyalaya, Chitrakoot, SATNA (M.P.) INDIA

Email : dileepkushwahacktd@ gmail.com

See end of the article for Coopted authors'

\begin{abstract}
The experiment was conducted at the Livestock Production and management unit, M.G.C.G.V. Chitrakoot - Satna M.P., during 2016 to April, 2016. Day old 45 broiler chicks (DOC) of same hatch were produced and reared in Deep litter system. The chicks were weighed, leg banded and distributed randomly into 5 groups of 9 chicks each as treatment. Chicks of each treatment were further divided into 3 sub groups of 3 chicks in each in Randomized Block Design (RBD). Chicks of each sub group were accommodated comfortably in deep litter providing 1 sq. ft./ chick. Chicks were fed standard starter ration upto 3 weeks age (1 to 21 days) and then broiler finisher ration upto 3-4 weeks (22-28 days). An experiment was conducted with DOC to 45 broilers chicks divided into fine groups $\mathrm{T}_{0}, \mathrm{~T}_{1}, \mathrm{~T}_{2}, \mathrm{~T}_{3}$ and $\mathrm{T}_{4}$ which were supplemented with Turmeric powder @ $1.0 \mathrm{~g}, 2.0 \mathrm{Sg}, 3.0 \mathrm{~g}$ and $4.0 \mathrm{~g} / \mathrm{kg}$ of broiler ration, respectively. Weekly observations were recorded for live body weight, weekly gain in weight, weekly feed consumption and feed conversion ratio (FCR) of birds for four Weeks. All the treatment groups $\mathrm{T}_{1}(724.17), \mathrm{T}_{2}(745.00), \mathrm{T}_{0}(695.92), \mathrm{T}_{4}(763.17)$ recorded significantly higher means for live body weight than of control $\mathrm{T}_{3}$ (769.25)FCR of chicks at first, second, third, and fourth week of age was recorded 1.61,1.83, 1.93, and 1.90, respectively. FCRs of broiler chicks due to treatment as well as due to week were significant
\end{abstract}

KEY WORDS....... Turmeric powder, Growth performance, Broiler chicks

HOW TO CITE THIS ARTICLE - Kumar, Dileep and Shukla, U.K. (2017). Effect of turmeric (Curcuma longa) powder in diet on growth performance of broiler chicks. Asian J. Animal Sci., 12(1): 81-84. DOI : 10.15740/HAS/TAJAS/12.1/81-84.

ARTICLE CHRONICLE - Received : 22.04.2017; Revised : 17.05.2017; Accepted : 27.05.2017 